Article

\title{
Evaluating the Impact of COVID-19 on Society, Environment, Economy, and Education
}

\author{
Vijay Kumar ${ }^{1}\left(\mathbb{D}\right.$, Hammam Alshazly ${ }^{2, *}$, , Sahar Ahmed Idris ${ }^{3}$ and Sami Bourouis ${ }^{4}(\mathbb{D}$ \\ 1 Computer Science and Engineering Department, National Institute of Technology, \\ Hamirpur 177005, Himachal Pradesh, India; vijaykumarchahar@gmail.com \\ 2 Faculty of Computers and Information, South Valley University, Qena 83523, Egypt \\ 3 College of Industrial Engineering, King Khalid University, Abha, Saudi Arabia; saharidris82@gmail.com \\ 4 Department of Information Technology, College of Computers and Information Technology, Taif University, \\ P.O. Box 11099, Taif 21944, Saudi Arabia; s.bourouis@tu.edu.sa \\ * Correspondence: hammam.alshazly@sci.svu.edu.eg
}

Citation: Kumar, V.; Alshazly, H.; Idris, S.A.; Bourouis, S. Impact of COVID-19 on Society, Environment, Economy, and Education. Sustainability 2021, 13, 13642. https://doi.org/10.3390/ su132413642

Academic Editor: Samuel Asumadu-Sarkodie

Received: 18 October 2021 Accepted: 29 November 2021 Published: 10 December 2021

Publisher's Note: MDPI stays neutral with regard to jurisdictional claims in published maps and institutional affiliations.

Copyright: (C) 2021 by the authors. Licensee MDPI, Basel, Switzerland. This article is an open access article distributed under the terms and conditions of the Creative Commons Attribution (CC BY) license (https:/ / creativecommons.org/licenses/by/ $4.0 /)$.

\begin{abstract}
The COVID-19 pandemic has caused drastic changes across the globe, affecting all areas of life. This paper provides a comprehensive study on the influence of COVID-19 in various fields such as the economy, education, society, the environment, and globalization. In this study, both the positive and negative consequences of the COVID-19 pandemic on education are studied. Modern technologies are combined with conventional teaching to improve the communication between instructors and learners. COVID-19 also greatly affected people with disabilities and those who are older, with these persons experiencing more complications in their normal routine activities. Additionally, COVID-19 provided negative impacts on world economies, greatly affecting the business, agriculture, entertainment, tourism, and service sectors. The impact of COVID-19 on these sectors is also investigated in this study, and this study provides some meaningful insights and suggestions for revitalizing the tourism sector. The association between globalization and travel restrictions is studied. In addition to economic and human health concerns, the influence of a lockdown on environmental health is also investigated. During periods of lockdown, the amount of pollutants in the air, soil, and water was significantly reduced. This study motivates researchers to investigate the positive and negative consequences of the COVID-19 pandemic in various unexplored areas.
\end{abstract}

Keywords: coronavirus; COVID-19; SARS-CoV-2; environment; economy; education; society

\section{Introduction}

A pandemic is an outbreak of an infectious disease throughout the whole world, spread by human interactions [1]. Many outbreaks of infectious diseases, such as the HongKong Flu, severe acute respiratory syndrome (SARS), Spanish Flu, and Asian Flu, have been studied in the literature [2]. In recent years, seven major outbreaks, namely hantavirus syndrome, H1N1 influenza, H5N1 influenza, SARS, Middle East respiratory syndrome (MERS), Ebola, and coronavirus, occurred [3]. Among these pandemics, the first to occur was H1N1 influenza, in 2009. H1N1 was responsible for more than 18,000 fatalities [4]. Similarly, more than 11,000 persons died due to the Ebola virus [5]. Both Ebola and SARS drastically affected socio-economic aspects in Africa and China [6]. Similarly, Zika virus spread in 64 different countries and affected more than 200,000 persons [2]. In 2009, H1N1 also disturbed various sectors such as healthcare, education, and tourism. Pandemics are not only responsible for high mortality rates but also have negative impacts on the economy, education, health, tourism, and the environment.

Recently, a new pandemic named coronavirus disease 2019 (COVID-19) arose in Wuhan, the capital of China's Hubei province [7]. COVID-19 is a very infectious disease caused by a new coronavirus named Severe Acute Respiratory Syndrome coronavirus-2 (SARS-CoV-2). SARS-CoV-2 has a higher affinity to human ACE 2 [8] than the original 
SARS virus strain [9]. SARS-CoV-2 is an enveloped positive-sense single-stranded RNA virus $[10,11]$. The virion releases RNA into the cell. Copies of the virus are created, which infect and capture more cells, especially those within the lungs. The outbreak of COVID-19 was first identified in Wuhan in December 2019. The World Health Organization (WHO) declared this outbreak as a pandemic on 11 March 2021 [12]. As of 21 September 2021, about 221 countries and territories have reported 4,716,983 deaths and 230,028,186 cases [13]. Table 1 depicts the statistics for the mortality rates in different countries.

Table 1. Statistics of mortality rate variation from 17th June 2020 to 13th September 2021 [13].

\begin{tabular}{ccccccc}
\hline \multicolumn{3}{c}{ COVID-19 Data as of 17th June 2020 } & \multicolumn{3}{c}{ COVID-19 Data as of 13th September 2021 } \\
\hline Area & Confirmed & Recovered & Death (\%) & Confirmed & Recovered & Death (\%) \\
\hline Worldwide & $8,428,600$ & 4411,367 & 450,452 & $225,488,198$ & $202,082,597$ & $4,644,372$ \\
\hline China & 83,265 & 78,379 & 4634 & 95,248 & 89,861 & 4636 \\
\hline Japan & 17,628 & 15,850 & 931 & $1,632,091$ & $1,478,100$ & 16,742 \\
\hline Singapore & 41,216 & 31,938 & 26 & 71,687 & 68,188 & 58 \\
\hline South Korea & 12,198 & 10,774 & 279 & 274,415 & 245,505 & 2360 \\
\hline Germany & 189,504 & 173,600 & 8927 & $4,087,109$ & $3,831,800$ & 93,128 \\
\hline United States & $2,234,471$ & 918,796 & 119,941 & $41,853,362$ & $31,871,868$ & 677,988 \\
\hline France & 158,174 & 73,667 & 29,575 & $6,905,071$ & $6,509,260$ & 115,517 \\
\hline Canada & 99,853 & 62,017 & 8254 & $1,542,280$ & $1,473,825$ & 27,198 \\
\hline Italy & 237,828 & 179,455 & 34,448 & $4,606,413$ & $4,349,160$ & 129,919 \\
\hline India & 367,264 & 194,438 & 12,262 & $33,264,175$ & $32,447,032$ & 442,907 \\
\hline Russia & 553,301 & 304,342 & 7478 & $7,140,070$ & $6,389,657$ & 192,749 \\
\hline Belgium & 60,244 & 16,684 & 9675 & $1,207,516$ & $1,105,366$ & 25,454 \\
\hline Iran & 195,051 & 154,812 & 9185 & $5,295,786$ & $4,568,236$ & 114,311 \\
\hline Switzerland & 31,187 & 28,900 & 1956 & 808,050 & 720,152 & 11,010 \\
\hline
\end{tabular}

In the initial phases of the COVID-19 pandemic, most countries put an emphasis on social distancing and screening people infected by COVID-19 to prevent the spread of the novel coronavirus. Travel restrictions were imposed by many countries to control infections by the novel coronavirus. Moreover, countries enforced strict lockdown policies to control the spread of COVID-19 and to decrease the mortality rates. Lockdowns have negative consequences on society, the economy, and education. However, it has a positive impact on the environment due to the low emission of pollutants from vehicles and industries [14]. Stock market crashes, manufacturing unit closures, and migrant labor movement are some of the major consequences of this pandemic. The demand and supply of goods were greatly affected by these lockdowns. There is a close association between the development of economic activities and environmental pollution [15]. Due to restrictions on economic activities, environmental pollution was drastically reduced. COVID-19 also affected the mental health of researchers and students due to quarantine and lockdown restrictions [16].

This paper provides a systematic analysis of the influence of COVID-19 in various sectors, such as society, environment, education, and globalization. The main contributions of this paper are as follows:

- Every aspect of society is analyzed from the perspective of the implication on their health;

- The effect of lockdowns due to the COVID-19 pandemic on water, air, and wildlife is studied in detail; 
- The impact of the COVID-19 pandemic on the agriculture, entertainment, and manufacturing sectors is discussed, and strategic plans for strengthening the agriculture sector are investigated;

- The influence of the COVID-19 pandemic on education is investigated, and both positive and negative consequences of COVID-19 on education are studied in detail.

The rest of the paper is structured as follows. Section 2 presents the effect of the COVID-19 pandemic on society. The impact of pandemic on environment is discussed in Section 3. The economy after the pandemic is presented in Section 4. Section 5 presents the implication of the pandemic on education. Section 6 discuss the impact of the pandemic on globalization. Section 7 presents a discussion on the impact of the COVID-19 pandemic on various sectors, and finally the concluding remarks are drawn in Section 8.

\section{Impact of COVID-19 on Society}

The COVID-19 pandemic has affected both the economic and health conditions of all age group people [17]. It shows a drastic impact on the various people, who are living below the poverty line, with disabilities, coming under older age group, belonging to indigenous communities, etc. The entire world has seen a rapid increase in the number of positive cases due to the lack of prior awareness of these types of coronaviruses. This can create a serious risk for humans and other living beings. Specific groups are striving for their basic amenities and medical treatment as young people are given more preference over old people. This is responsible for generating the feelings of inequality, discrimination, and isolation among the weaker sections [18]. The COVID-19 pandemic has created many trade-offs unknowingly in our society. Although, the coronavirus can attack on any age group of people, tobacco taking peoples are more vulnerable than others as this virus has a tendency to attack on lungs and causes severe acute rupturing of respiratory system [19]. This virus created major shifts in the way of thinking, socializing, communication, and living. Table 2 shows the distribution of age and sex based confirmed COVID-19 cases.

Table 2. Distribution of age and sex based confirmed COVID-19 death cases in the United States on 9 August 2021.

\begin{tabular}{ccc}
\hline Age & Male & Female \\
\hline under 1 Year & 54 & 44 \\
1-4 Years & 26 & 24 \\
5-14 Years & 77 & 61 \\
15-24 Years & 736 & 496 \\
25-34 Years & 3380 & 2015 \\
35-44 Years & 8665 & 4902 \\
45-54 Years & 23,386 & 12,270 \\
55-64 Years & 53,443 & 31,416 \\
65-74 Years & 87,264 & 56,756 \\
75-84 Years & 97,661 & 75,994 \\
85 and above & 79,113 & 106,075 \\
\hline
\end{tabular}

\subsection{Older Generation}

The initial reports on the COVID-19 pandemic revealed that approximately $80 \%$ fatalities occurred in the peoples whose age over than 65 years [20]. The International Human Rights Law guarantees everybody to obtain the highest attainable standards of health, in contrast to which during the shortage of services in a pandemic, the treatment of older people was perceived as of less importance than that of young and healthy people [21]. The elderly population with diabetes, asthma, and cardio-vascular attacks, are more susceptible to the infection caused by coronavirus. To combat with the scarcity of essentials amid the pandemic, isolating oneself is an essential measure that resulted in further increment in emotional imbalance in society [22]. Due to poor health care systems 
in most of the countries, older peoples are giving less importance than the younger ones. Hence, governments should design the proper plans to strengthen their health care systems for handling the pandemic situation.

The old peoples also suffer from depression and mental health problems. The modern technologies are unable to mitigate the problems associated with old peoples [23]. In future, the webinars or workshops on digital technology should be organised for elderly population.

\subsection{Young Generation}

Young population is one-fourth of the total world's population. Young people participated in various economic and social activities enthusiastically. They are working to help the economic weaker sections. They provided innovative ideas to solve the social and economic problems [24]. However, young persons were suffering from the social and economic impacts of the COVID-19 pandemic.

It is observed from a report that 267 million out of 1.8 billion young population (i.e., age from 15 to 24) were not involved in education and employment before the pandemic [25]. After the COVID-19 pandemic, this crisis becomes more excavate than the previous situation. According to a global survey on Youth and COVID-19, there is a $42 \%$ reduction in the income of employees [26]. In developing countries, young employees experienced more reduction in their income and working hours. This have put enormous psychological effect on the young population. It is found that $17 \%$ of young population suffer from depression and angst [27]. Young population feel apprehensive and uncertainty about the future due to disruption in business and education, social isolation, and personal stress [28]. Young population has less severe health impacts than the elderly population [29].

There is a need to implement employment policies to mitigate the unemployment crisis arises due to the COVID-19 pandemic. The sports activities and mental health services should be integrated in the employment policies to alleviate the mental health issues.

\subsection{Disabled People}

The disabled population are facing various challenges such as medical care, personal hygiene, and implementing social distancing. These persons may be dependent on external help for doing their daily routine and solving other issues [30]. Disabled population are more vulnerable to the COVID-19 pandemic. The following challenges are confronted by disabled population during this pandemic [31].

- Incapability to wear mask

Some disabled persons are unable to wear mask due to their disability or health issues. Some persons may feel uncomfortable to breathe and panic. Some persons wearing masks are unable to communicate with other through the lip reading [32]. Hence, there is no need to make it compulsion that every disabled person should wear a mask.

- Inaccessibility of telehealth services

Visually impaired persons are unable to access cognitive delays. For deaf, the sign language interpreters are required to access the telehealth services.

- Inaccessibility of COVID-19 testing centers

The disabled persons are unable to visit the testing centers independently. They required a safe ambulance facility, which is impossible in this pandemic situation.

- Impact of social distancing

The social distancing plays a vital role in preventing the outbreak of coronavirus. Without the assistance of other persons, disabled persons face complications in doing their daily activities and also suffer from mental problems [33].

- Incompetent of health policies In the initial phase of the COVID-19 pandemic, the health policies did not consider the requirement of support staff for disabled persons. Due to this, many persons experienced adverse effect on their health without the helper's assistance. 


\section{Impact of COVID-19 on Environment}

Nowadays, the lifestyle of human beings has caused a drastic impact on environment. The population has increased from 1 billion (1800) to 7.7 billion in 2020 [34]. Human beings are drastically utilizing the natural resources for new developments of industries, infrastructure, and habitats. Due to the increase in human population, the demands of dairy and meat products, such as eggs, meat, and milk, have also increased. This has encouraged the poultry farming and livestock raising, which are actually considered as the main door for persuading the transmission of various viruses from the wildlife world to the human world [35]. The reduction in green cover of the Earth will severely affect our lives in the long run. Amazonian evergreen forests are known as the carbon stores of ecosystem. According to the World Wildlife Fund, forests cover more than $30 \%$ of the Earth's surface [19]. It is predicted that human beings will face a complete loss of rainforest cover in the basin by 2100 due to the decrease in rainfall and the increase in temperature [36]. Exploitation of forest vegetation, burning of fossil fuels, releasing poisonous exhaust from industries and transportation are responsible for disturbing the ecosystem.

It has been observed from the study of the United Nations Environment Programme (UNEP) and International Livestock Research Institute (ILRI) on Zoonotic that epidemics will be occurring more repeatedly in near future due to the drastic change in climate and food chain [37]. The unexpected changes in environment and wild life disturbed the balance in food chain. The wild animals left their habitats and are moving towards the cities or villages due to large scale deforestation. This also led to the transmission of novel microbes and pathogens from these animals to human beings. Hence, the food cycle is affected severely and is responsible for more frequently occurring zoonotic diseases in near future [38]. There are millions of undiscovered and undefined virus species, which are present in animals. They may severely infect the human beings. According to Intergovernmental Science-Policy Platform on Biodiversity and Ecosystem Services (IPBES) report, if there exists a genetic diversity, it will help in building resistance among animal population [39]. It also reduces the outbreak of infectious diseases. Recently, farmers are using pesticides and fertilizers in crops to evade the insects, weeds, and various diseases. However, the extensive usage of pesticides and fertilizers may help the pathogens to develop more resistance towards the medicinal treatment of zoonotic diseases.

\subsection{Impact on Air}

The COVID-19 pandemic has affected the environment in more lethal manners. During this pandemic, air quality is significantly improved due to reduction in human activity and manufacturing operations [40]. This pandemic has helped the nature in rejuvenating itself. Rivers are clean and skies are clearer. A study on the outbreak of SARS reported that the mortality rate in China's most air polluted areas was twice as high as in the least polluted ones [41]. The pathogens along with pollutants can form a strong bond, which might help them to stay intact in atmosphere for long duration and gives them an easy way to enter into the human body. According to Annual State of Global Air Report [42], 95\% of planet's population is breathing unhealthy air. Due to air pollution, 1.61 million deaths are reported in India every year. In similar fashion, China faces 1.58 million deaths annually.

During the lockdown period, air quality is significantly improved due to reduction in $P M_{2.5}, \mathrm{SO}_{2}$, and $\mathrm{NO}_{2}$. This may led to reduction in the mortality rate. The researchers from Harvard University's T.H. Chan School of Public Health found the association between the number of COVID-19 deaths and $P M_{2.5}$ levels. They stated that the small increment of one microgram per cubic meter of $P M_{2.5}$ in air had led to $8 \%$ higher death rates $(95 \%$ confidence interval) during SARS-CoV-2 [43]. The concentration of various harmful gases was greatly reduced in various countries after the lockdown. In the USA, $49 \%$ reduction in $\mathrm{NO}_{2}$ and $37 \%$ in $\mathrm{CO}$ concentration was observed in the air quality [44]. A drop of $70 \%$ in harmful nitrogen dioxide was analyzed in Delhi after the lockdown [45]. Figure 1 depicts the impact of lockdown on the concentration of $\mathrm{NO}_{2}$ in China [46]. It is found from Figure 1 that there is no rise in the levels of pollutants even after the new year festival. 
Pollutant Drops in Wuhan-and Does not Rebound

Unlike 2019, $\mathrm{NO}_{2}$ levels in 2020 did not rise after the Chinese New Year.

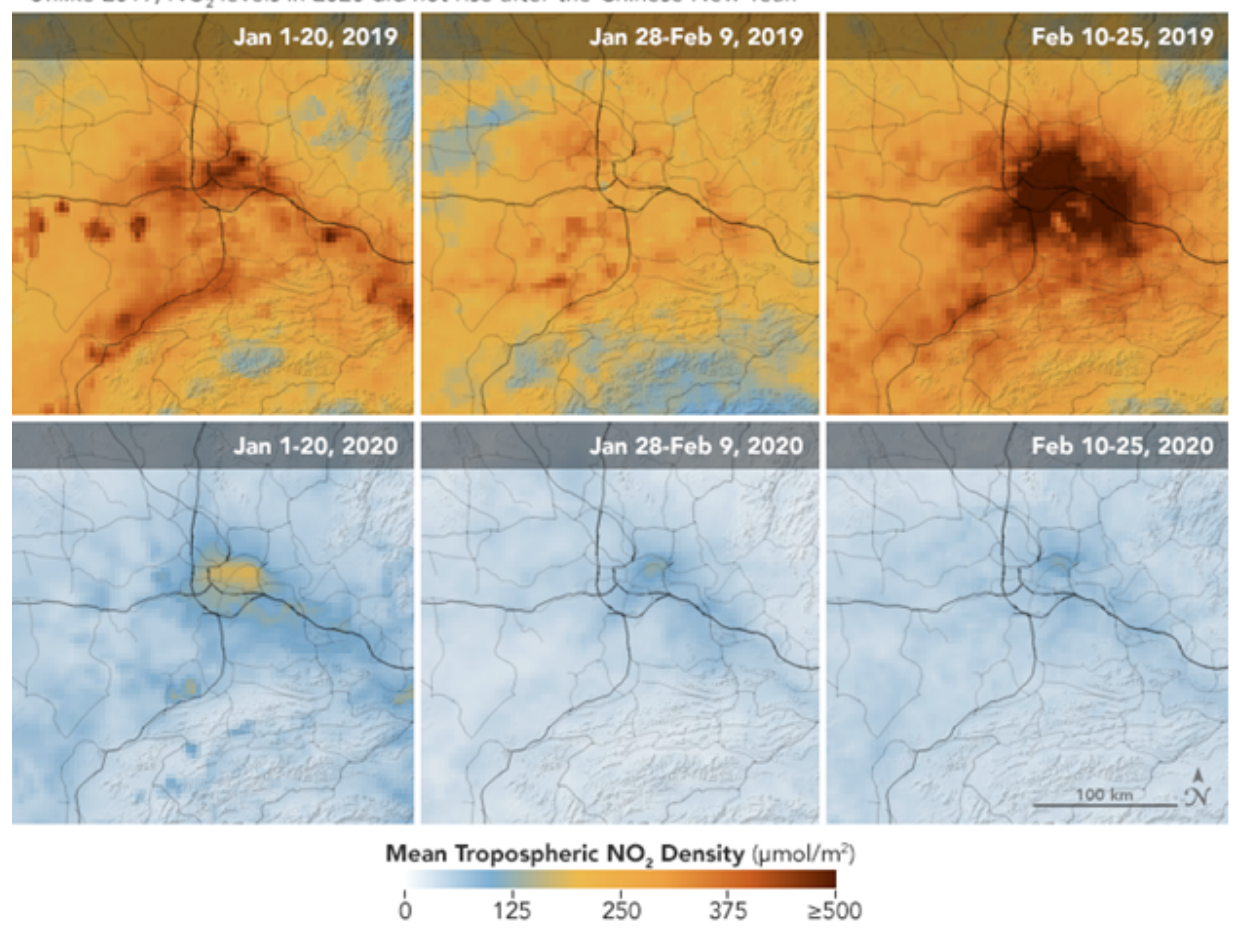

Figure 1. Impact on Nitrogen Dioxide level due to COVID-19 (1 January 2019-25 February 2020) [46].

The concentration levels of air pollutants are drastically reduced during this pandemic. This may led to a decrease in the number of patients who face asthma, lung problems, or heart attacks [47]. These changes are not perennial after the post-COVID-19 situation. The government should take some preventive measures to maintain better air quality. The renewable energy systems should be widely used in manufacturing industries [48]. The government should encourage the peoples for installing the solar panels. Affordable public transportation should be increased to reduce the road traffic and pollution. Tax reduction, subsides, and financial incentives should be given on the purchase of electrical vehicles.

\subsection{Impact on Water}

In this pandemic, the formation of acid rain is drastically reduced due to the decrease in air pollutants. The industrial wastewater was extremely reduced due to the lockdown period [49]. The restriction in religious activities, fishing, and social functions may led to less disposal of solid waste. The self-cleaning properties of river are improved with better water quality. The dissolved oxygen level in river is increased to approximately $5 \mathrm{mg} / \mathrm{L}$ in Yamuna River, Delhi [50]. In Italy, the water of Venice's canals was cleaner than the previous year [51]. The fishes are seen in the Venice's canals. The marine ecosystem is also recovered after the decline in fishing activities and reducing the blue carbon [52].

There is no evidence about the survival of coronavirus in drinking water supplies. However, it is possible in untreated drinking water. Since the structure of SARS-CoV-2 is the same as that of the previously detected coronaviruses, the same precautions have to be taken, which were mentioned for the previously discovered coronaviruses [48]. Adopting frequent hand hygiene and using water disinfection can help in reducing the risks associated with SARS-CoV-2. Governments have to design the proper rules and regulations for an efficient treatment of solid and water waste received from the industries. International and national rules should be designed to handle the overfishing problem. 


\subsection{Impact on Wildlife}

The wildlife economy plays a crucial role in effectuating the several sustainable development goals and supporting local communities whose economic dependency greatly relies on wildlife. According to the World Travel \& Tourism Council [53], wildlife tourism supports 21.8 million jobs across the World or $6.8 \%$ of the total travel and tourism jobs. The lockdown in various countries, closure of international borders and shutting down of transport have severely affected this sector. Most of people left this sector. Due to less cash flow, this sector is almost closed. The protection of wildlife and endangered species is facing a big blockage amid this pandemic [54]. This also led to the decrease in the funding of the anti-poaching units. The poaching activity has been increased due to the less strict rules and regulations. In addition to this, jobless people were dependent on wildlife for their living.

Another major concern is the illegal activity. It will speed up the transmission of SARS-CoV-2 virus from animals to humans as these animals are usually kept without proper maintenance of hygiene. These animals might be the home for various pathogens and undiscovered viruses. It is observed that $75 \%$ of new infectious diseases come from the consuming animals [55].

\section{Impact of COVID-19 on Economy}

The economy of any country depends on its agriculture, industries, businesses, government investments, import, and export. The COVID-19 pandemic directly affected all the sectors. The economists over the entire world are analyzing the impact of this pandemic on the global economy [56]. The global economic growth will be subjected to $1.6 \%$ decline in 2020 and $3.2 \%$ in 2021 [57]. It is predicted from the literature that China will be affected by this pandemic. The economic growth in China may be declined by $2.4 \%$ as compared with the earlier estimation (i.e., 5.7\%) [57].

International Monetary Fund has also estimated that the global economy will fall off to 3\% and global Gross Domestic Product (GDP) will lower by 3\% [58]. Its impact can be easily seen on the various sectors of different countries who are depending on China for trade or manufacturing [59]. It is also estimated that services and manufacturing sector will face tremendous losses. The tourism and travel industry will be severely affected. International entertainment industry and sports' brands industries will face a severe loss in their revenues and marketing [60]. Thus, the impact of the COVID-19 pandemic on economy is going to be very drastic unless the reliable and proper strategic plans are developed to handle this affray.

\subsection{Agriculture}

In order to discontinue the outbreak of COVID-19, lockdown was imposed on most of the countries. This affected the food-supply chains, availability of crops, and logistic services [61]. These restrictions could have led to the rise of traumatic condition for the people living in developing countries. Agriculture is the most crucial service that cannot be put in an immobilize state. However, the collective actions have been taken by various countries for surplus food production and cold storages. This will help those countries who are dependent on others for their food supply [62]. Undoubtedly, the pandemic greatly affected the economy and led to income reductions. They might face unemployment in near future. The government of various countries are putting their effort to balance both the lives and livelihoods [63]. They are investing in recovery measures and safe food delivery to the unemployed and poor people. Figure 2 depicts the impact of COVID-19 on agriculture. 


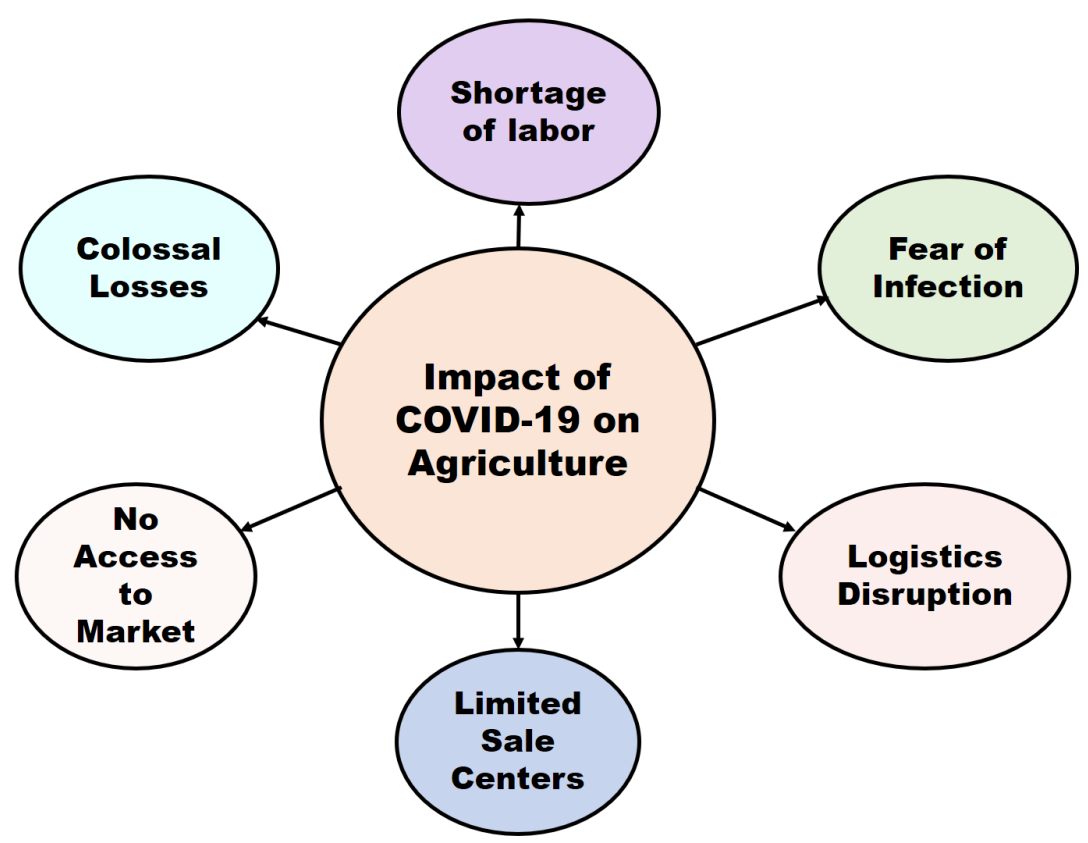

Figure 2. Impact of the COVID-19 pandemic on the agriculture sector.

The governments are taking valiant measures to fight against the chronic crisis in food-supply chains. Shortage of labor may create the stumbling blocks for the farmers. The United Nation World Food Program has estimated that about 130 million and more (i.e., from 135 to 265 million) population will face acute food insecurity by the end of 2020 [64]. The World Bank Group is closely associated with governments for monitoring the domestic food and agriculture supply chains. They are also investigating the impact of unemployment and income on their food buying capabilities [65]. The short and long term financing strategies are required to rebuild the existing projects. Recently, unanticipated climatic conditions and various insect attacks are becoming a new challenge in front of farmers and governments. Both are taking appropriate measures to implement the control operations for preventing the agriculture farmlands and crops. Figure 3 illustrates the strategic plans for strengthening the agriculture sector after the post-COVID situation.

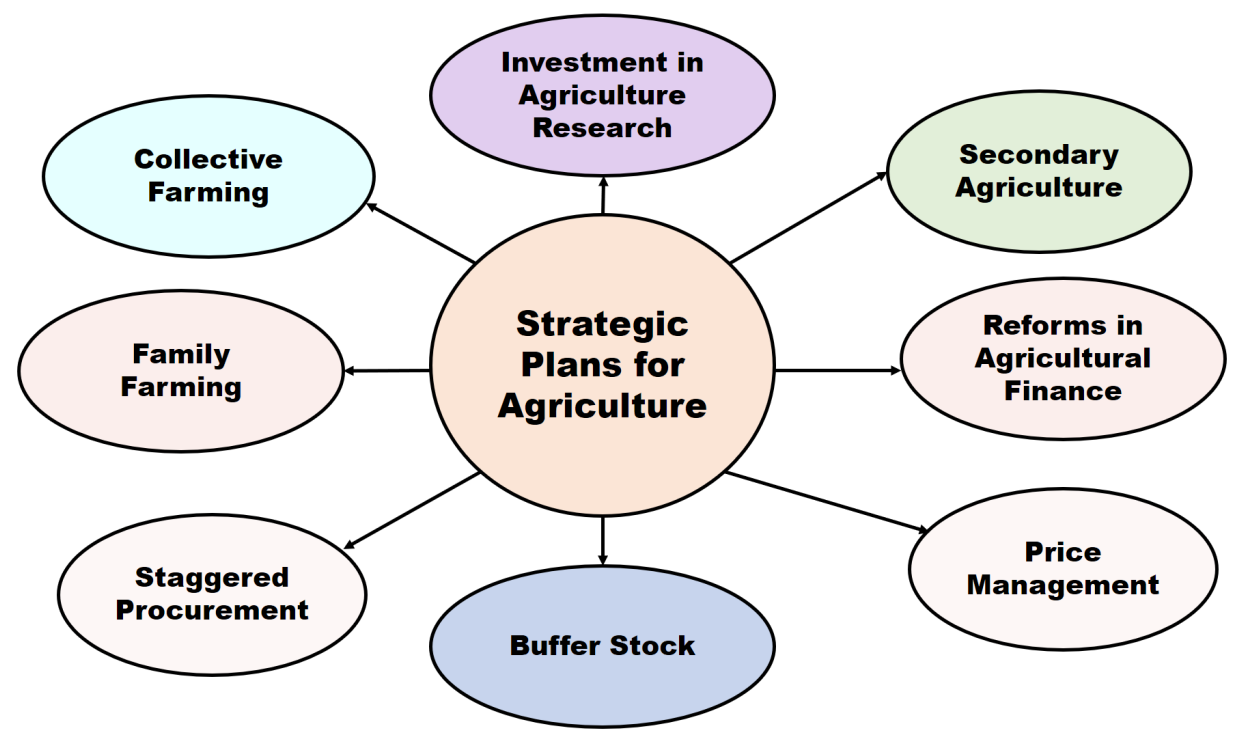

Figure 3. Strategic plans for strengthening the agriculture sector after post-COVID [66]. 


\subsection{Business}

The COVID-19 pandemic has drastically affected the micro, small, and medium enterprises (MSME). According to All Indian Manufacturer Association, 19\% to 43\% of different enterprises may disappear if the crisis persists for long duration (i.e., more than 8 weeks) [67]. Due to lockdown and quarantine period, people have shown limited working possibilities. Consumers are purchasing the essential and limited items that will directly affect the demand-supply chain [68]. Goods which are subjected to import-export market, will see a relative decline in their market due to the seizing of trade across countries. The Economic Times reported that there is worry about the MSME sector, which accounts for third of India's manufacturing output and 45\% exports affect 63 million households [69].

In current scenario, wages and salaries are big issues. There are zero revenues due to shutdown of manufacturing units. High bills, loans, and wages will be impossible for these MSMEs in near future. MSME sector has created more than $90 \%$ of jobs in India. These jobs may be disappeared from various sectors [70]. The Global Alliance for Mass Entrepreneurship created a $\$ 100$ million small stabilization fund to help the small business in this crisis [71]. The businesses are facing loss due to the struggle in the delivery of goods, limited transportation facility, and unavailability of migrant workers. In India, 12 million people may lose their jobs in the hospitality industry.

After COVID-19, the restarting of manufacturing units might be a difficult task. There are many challenges, such as liquidity crunch, labor shortage, and strict rules to maintain the appropriate COVID-19 behavior.

\subsection{Entertainment}

The COVID-19 pandemic has also affected the film industry. However, digital commerce and technology have been raised in this discussion [72]. This is one of the most prominent sectors. Online gaming, radio, and digital media subscriptions, and the over-thetop (OTT) media service platform are largely increased in this pandemic situation. They may provide more revenues in the upcoming years. Whereas, film industry, theater, and live events are facing a huge loss as stated by the Event and Entertainment Management Association (EEMA) [73]. The reason behind dwindling of these revenues is the shutdown of theaters and multiplexes. These setbacks are not limited to the end of the pandemic. According to the post-COVID-19 conditions, people will show variable behavior in the acceptance of outward media. Many people may prefer the home media [74]. Large numbers of people are dependent on this sector for their employment. They might face the unemployment after this pandemic situation. The new and innovative ideas are required for delivery of digital content and events such as virtual live events. The advance cloud and remote work stations are required for implementing the novel ideas.

\subsection{Travel and Tourism}

Travel and tourism play a vital role in the social and economic development of any country [75]. Tourism industry indirectly affects several sectors, such as labor, agricultural products (food and beverage), transport, and accommodation. According to the Global Trade Analysis Project (GTAP), both skilled and unskilled labor require 30\% share of tourism expenditure in developed and developing countries. Figure 4 depicts the various inputs required for the tourism industry [76]. 


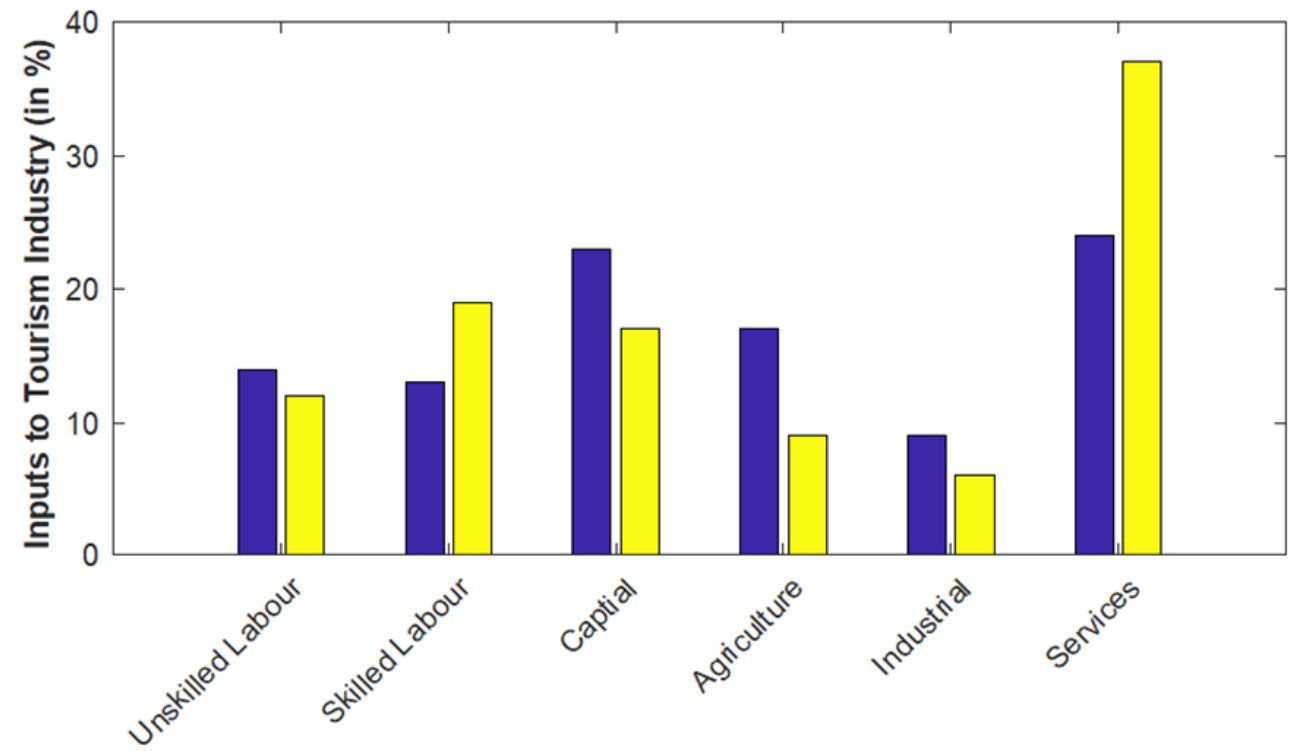

Figure 4. Contributions of different sectors towards the tourism industry [76].

However, this industry faces the hardest-hit in the pandemic situation. COVID-19 greatly affected the travel and tourism industry. The emergency measures were applied on tourist locations that put a large impact on the people's mobility [77]. According to the United Nations World Tourism Organization (UNWTO), the arrivals of international tourists was decreased by $72 \%$ from January 2020 to October 2020. Due to this, the export revenues have a loss of USD 935 billion. This loss is approximately ten times more than the loss made in 2009 under the economic crisis [78]. Most of the restaurants face high operating costs due to the maintenance of social distancing, sanitation, and hygiene. Hence, restaurants were closed due to less number of tourists and high operating cost. Some restaurants were also converted into the quarantine centers. The sustainability of travel and tourism industry is a challenging task in this pandemic situation. Figure 5 shows the deviation of the number of foreign tourists in the current year over 2019.

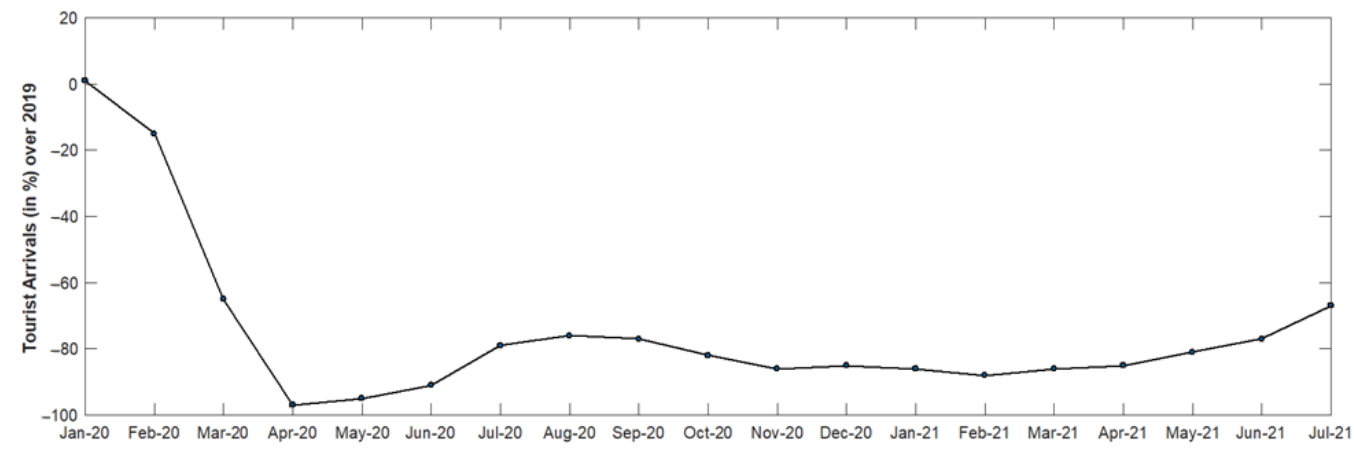

Figure 5. Foreign tourist arrivals in 2020 and 2021 [79].

The tourism industries of both developing and developed countries suffer from this crisis. According to UNWTO, the tourist arrivals were reduced by $60-90 \%$ for developing countries. During this pandemic situation, domestic travel has greatly raised [80]. This will slightly affect the economy of developing countries. The developing countries mainly depend upon the international travel. Indian tourism is estimated to face a great revenue loss of INR 1.25 trillion the year 2020 due to the closure of hotels and aviation industry. According to CARE report, Indian tourism industry expects a revenue loss of INR 69,400 crore due to the suspensions of international flights $[81,82]$. It was mentioned that there will be $50 \%$ loss in foreign exchange earnings in 2021. Indian Airlines has reported a loss of 
USD 600 million for January-March quarter. The government of India is planning a rescue package of up to INR 100-120 billion. It has been decided to put off the taxes to a later time on Indian aviation sector until it comes back to its feet. The companies could be permitted to pay the taxes interest-free in next tax-cycle. In South Africa, the tourist arrivals were reduced by $71 \%$ during this pandemic situation [83]. The revenue was reduced from 15.8 million to 5 million in 2020. South Africa did not receive any visitors from April to September 2020. During this crisis, Australia faced $81.4 \%$ reduction in the number of tourists. However, the United Kingdom (UK) and Zimbabwe received a large number of overseas tourists as compared to other countries. After the lift up of restrictions in the UK, the number of visitors was greatly increased from 19,862 in April 2020 to 267,942 in August 2020 [79]. Figure 6 shows the number of tourist arrival in different constituents in 2021.

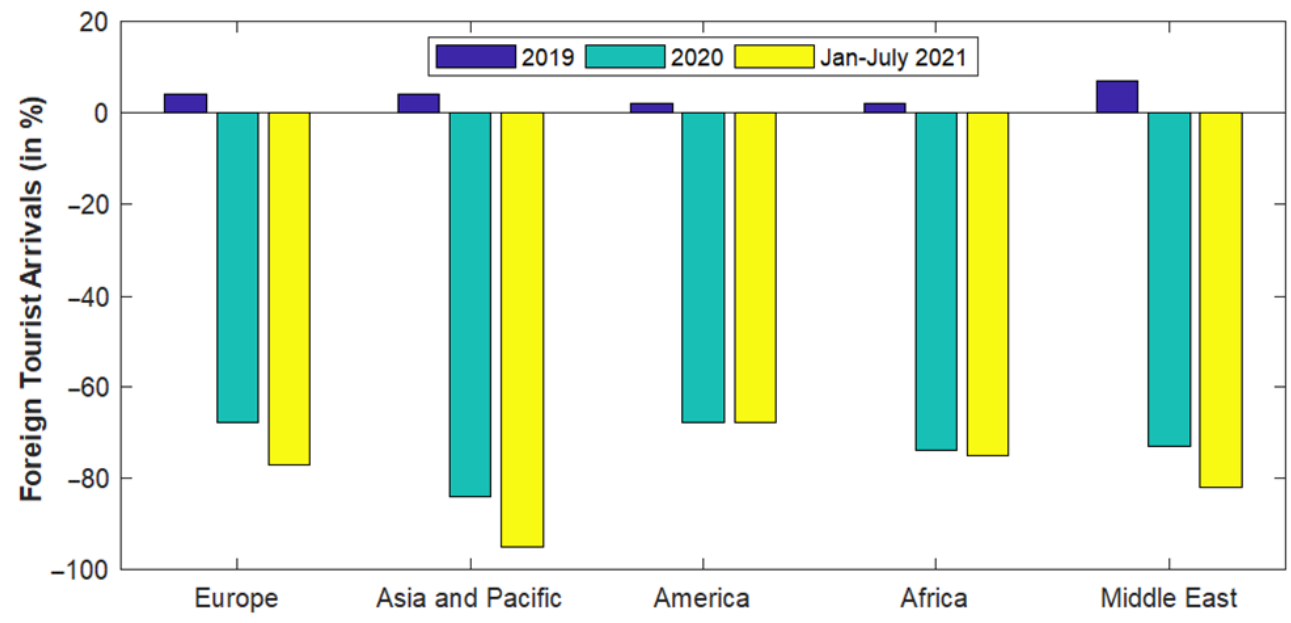

Figure 6. Number of foreign tourist arrivals in different constituents [79].

This pandemic also affected the Air Cargo and increased the export cost. One possible solution is to reduce the size of their fleets or modernize their fleets. The aviation company can design new plans for well-planned deliveries, more fuel efficient models or by retaining order planes, and reducing capital expenditure on new aircraft.

\subsection{Service and Manufacturing Sectors}

China is the major supplier of raw materials, small parts and tools to various manufacturing industries across the globe [84]. Due to seizing of borders across countries, world's manufacturing units especially those which are dependent on China for supply of raw material are facing a big blockage in their production. Many manufacturing units either switched to a smarter model or switched to the production of medical related products during this pandemic. The United Nations Conference on Trade and Development (UNCTAD) has estimated a shrink of $5 \%$ to $15 \%$ in the global foreign direct investment as the shutdown of manufacturing sector [85]. The electronics and electrical companies are significantly affected from this pandemic as most of their critical parts are supplied from China. According to the International Labor Organization (ILO), it is estimated that around 25 million people will face unemployment at a global level in pandemic [86]. In the service sector companies, very few peoples are coming to their offices. Most of the employees are doing their work from home.

\section{Impact of COVID-19 on Education}

The educational system is drastically affected from the COVID-19 pandemic. Nationwide lockdown imposed the closure of schools, colleges, tuitions, examinations, and universities. According to the UNICEF, $98.5 \%$ of the worldwide student population is affected from the closure of education hubs in around 186 countries [87]. In total, $60 \%$ of children's learning loss is observed in the least educated family. It was assumed that the closure of educational institutions may help in preventing the spread of coronavirus. Recent 
studies on COVID-19 have predicted that the closure of educational institutions has decreased the mortality rate by $2 \%$ to $4 \%$ [88]. This scenario can be changed if the appropriate COVID-19 behaviors are not adopted.

Another study shows that although children can catch coronavirus, they rarely show severe symptoms and they can be act as an intermediator for coronavirus. That is why the educational institutes were closed to stop the outbreak of COVID-19. However, the closure of educational institutes is not the best solution. Its effectiveness can be varied with respect to the timeline of the outbreak of COVID-19 [89]. If it was implemented in the early phase of COVID-19, then this will show major impact on the depreciation of mortality rate. Whereas, if this step is taken in the later phase, then this may not display major impact on the mortality rate. After the reopening of educational institutions, a small increase in the death rate was observed [90].

The closure of educational institutes directly affect students, teachers, staff members, and their families. The main impacts have been shown in various sectors over the long term run [89] including:

- Global Stock Market

Education put a great impact on the global stock market. Highly educated traders have utilized the new technologies and tactics to analyze the stock market and gain more benefit. Due to this pandemic, less experienced traders will be produced from the institutions.

- $\quad$ Food Insecurity

Students and their families who directly depends upon the mid-day meals. In India, more than 100 million children are taking mid-day meals. They faced food insecurity in this pandemic.

- Internet Services

Internet services and digital technologies such as tablets, mobiles, and laptops are required for online learning. The high demand of these items may led to an increase in their cost. The students who are living in rural areas, were facing lack of infrastructure for accessing the Internet facilities.

- Healthcare Issues

The families who currently do not have any way of earning bread are expected to face many healthcare issues.

The UNESCO has provided suggestions for adapting distance learning methods and online learning programs. In India, the central government has taken various preventive measures. The Indian government declared the complete closure of educational institutions in the earlier phase of the COVID-19 pandemic. However, this closure affected various competitive examinations, internships, placements, counseling operations of students, etc. Figures 7 and 8 show the positive and negative consequences of the COVID-19 pandemic on education. 


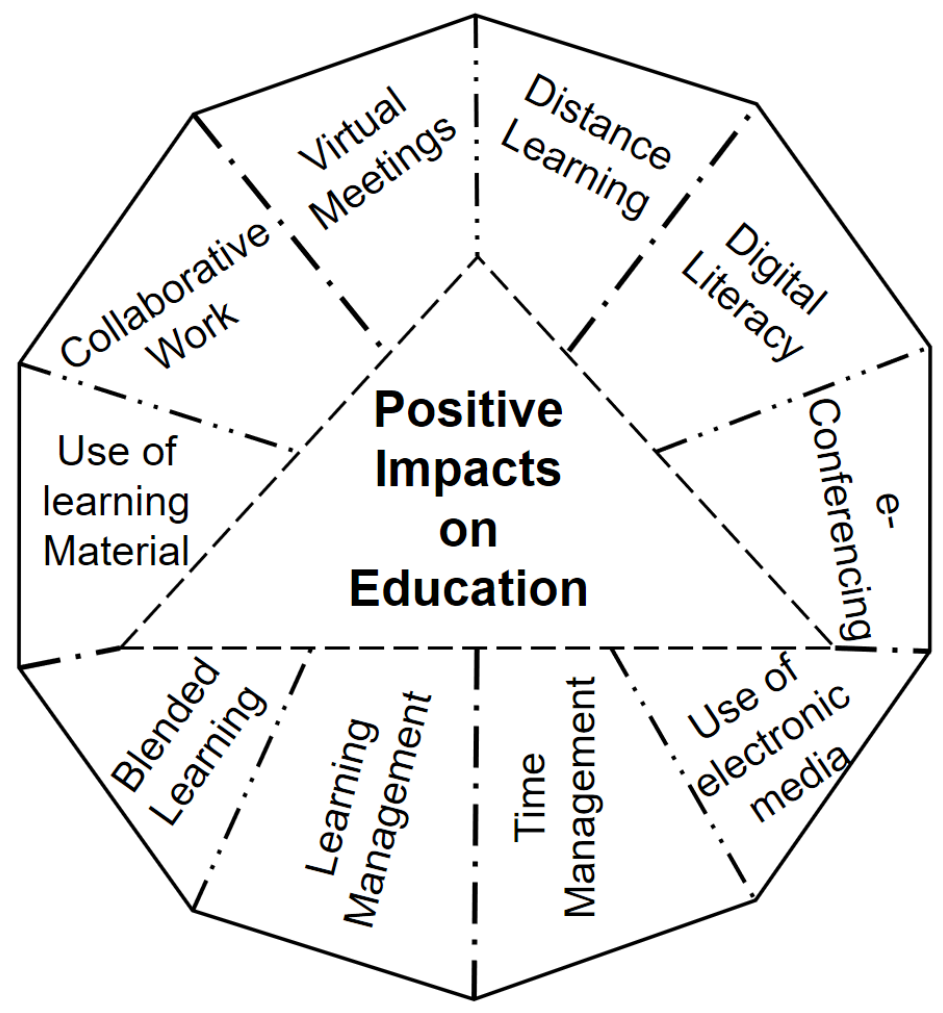

Figure 7. Positive impacts of COVID-19 on education.

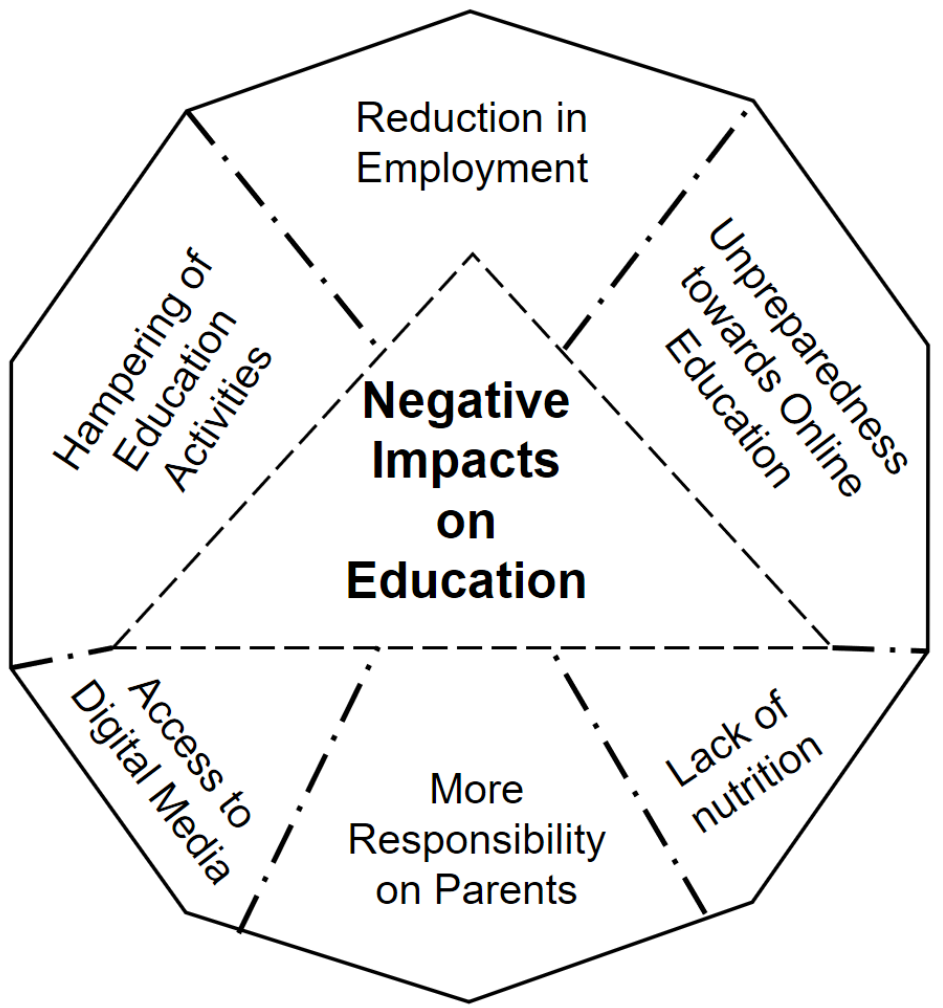

Figure 8. Negative impacts of COVID-19 on education.

\subsection{Impact on Students}

Due to the closure of educational institutions, students have adopted the distant learning methods. However, still many schools are striving to execute the online learning. Some children are unable to take the electronic gadgets and an appropriate Internet facility 
in their areas [91]. This imposed a major challenge in the use of distant learning program. For working parents, it is very difficult to keep an eye on their ward and maintain a balance in their home environment. To overcome the above-mentioned problems, there is a need to develop a strong infrastructure system [92]. It will accelerate the learning of students suffering from the learning loss during summer or weekend breaks. It will also help to grab few extra global opportunities of interacting and learning outside their school by connecting them to the entire world. Figure 9 depicts the impact of COVID-19 on students.

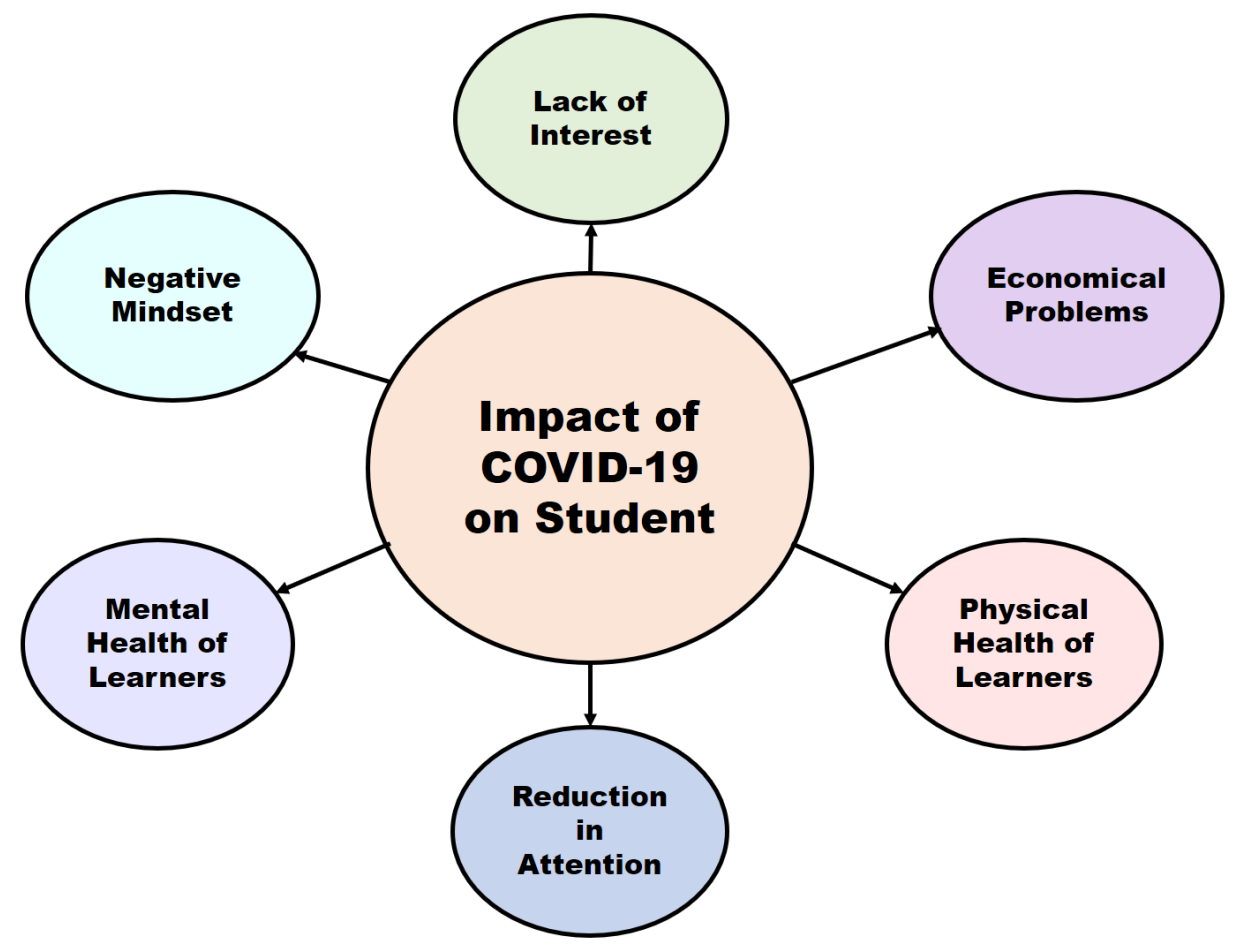

Figure 9. Impact of COVID-19 on students.

In India, the government started the Massive Open Online Courses (MOOCs) and online courses for both instructors and students. The online resources such as the National Repository of Open Educational Resources, DIKSHA, and e-Pathshala were developed to cover the syllabus of class 1st to 12th standard [93]. The database of online courses named as SWAYAM was developed for graduate and post graduate students. Thirty-two Direct To Home (DTH) channels were made accessible for online classes. These were available on all the major cable connection.

\subsection{Impact on Research}

Due to online learning, a huge traffic on the Internet has created a great strain for the service providers. Teleconferencing or Videoconferencing were widely used to communicate with experts in-place of meeting rooms [94]. Only $2 \%$ of researchers were working in the field of virology before this pandemic. Nowadays, a large number of researchers and laboratories have been dedicated to COVID-19. This has led to an approximate 10-15\% increase in research in the biomedical field [95]. On the other hand, artificial intelligence and machine learning researchers have been conducting extensive research studies with several published articles in various reputed journals [96-100]. Moreover, a large number of research articles on COVID-19 has been uploaded on preprint servers such as bioRxiv, medRxiv, and arXiv. The potential lapses were found during the peer review process, which greatly affect the prestige of major journals [101]. The Lancet and other prestigious journals retracted the published articles and findings [102]. In this pandemic, a collaborative platform was made for knowledge gathering and expertise sharing among researchers and scholars [103]. 
Various reputed laboratories across the world have closed their doors for visitors, employees, and non-essential staff. The scientists started their work at home. Many researchers and scientists of reputed laboratories have collaborated over cloud computing. They have pooled resources to access supercomputers from IBM for doing research [104]. High Performance Computing Consortium on COVID-19 is also being used for various critical purposes such as:

- $\quad$ Forecasting the spread of the disease;

- Discovery of vaccines for COVID-19;

- $\quad$ Screening of chemical compounds to design new COVID-19 vaccine.

\section{Impact of COVID-19 on Globalization}

The main motivation behind globalization is to improve the life expectancy and reduce newborn mortality rate through different aspects of globalization [105]. Different aspects of globalization can be involved such social, economic, and political ones (see Figure 10) [105]. The developing countries focused on the economic aspect of globalization, which promoted wealth creation to improve the health of their populations, while developed countries focused on social integration.

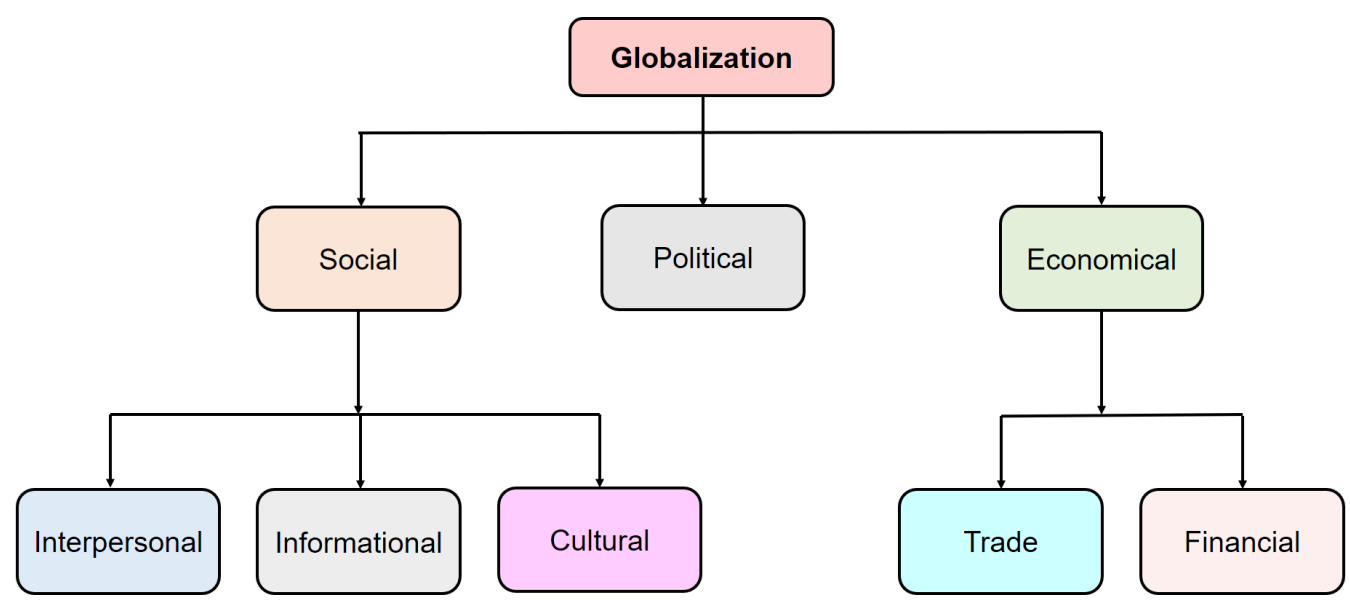

Figure 10. Main aspects of globalization.

During the COVID-19 situation, social globalization plays a significant role in handling the containment of coronavirus. The countries with high social globalization have taken quick actions to impose the travel restrictions and other control measures. The countries with higher political globalization have less interested to impose the travel restrictions [106]. They have taken a lot of time to take the strict travel restrictions. However, there is no strong association between economic globalization and travel restrictions. A country with more political globalization, cultural, and interpersonal has less expectation to impose the travel restrictions in this pandemic situation [107]. Most of the countries whose policies to support the globalization have the least interest to implement any restrictions on travel.

According to the Internal Labor Organization, the unemployment has increased by approximately 25 million globally [108]. The trade of Los Angeles was reduced by $22 \%$ in the first quarter of 2020. The developing countries such as South Asia and Africa observed 3.6\% fall in their GDP. Some food chains declared bankruptcy. Thailand and Malaysia have been greatly affected by the COVID-19 pandemic. There has been a $14 \%$ downfall in job related to travel and tourism industry [109]. It has also been noted that the economic impact exceeds USD 220 billion in the United States. After this pandemic, governments are focusing on developing the domestic supply chain for some important products. For instance, South Korea has used robots in production industries. It is also noted that vaccines and medical equipment are being delivered from developed countries to developing countries. 


\section{Discussion}

Recently, a significant improvement in the tourism sector has been observed in some countries and a decrease in others. As travel restrictions are lifted, travelers are gradually starting to travel in Europe and other places in the world. In Mexico, the same number of international tourists were received in June 2021 as in 2019. In July 2021, 35\% and 49\% fewer tourists arrived in France and the United States, respectively, than in 2019 [105]. In July 2021, the Caribbean had an $11 \%$ increase in tourism compared to 2020. During the January-July 2021 period, Asia experienced a 95\% decrease in international travel compared to the same period in 2019 [109].

We have noted also that during this pandemic, more globalized countries implemented strict travel restrictions as compared to less globalized ones. Indeed, globalized countries have a large number of confirmed cases due to a slow response towards the resulting cases [110]. In the early phase of COVID-19, European countries with significant health facilities did not set travel restrictions. The economic and political aspects had a great impact on the choice of strict travel restrictions [111]. In addition, a country with more social and cultural aspects requires an extra time duration to implement the travel restrictions. After this pandemic, the worst-hit countries put in place anti-trade policies and measures without relying on developed countries. However, globalization is responsible for low inflation. The globalization will not be ended even if the de-globalization gains some momentum.

Both positive and negative impacts are observed in the field of education and research. In particular, about one billion of students were affected from the preventive measures taken by the governments [112]. Thanks to this pandemic, governments have taken an initiative to develop online learning platforms. The Internet connectivity is still one of the main challenges for implementing online learning especially in rural areas. Because of the pandemic situation, researchers have not had enough time to do their research work. Many of them were preoccupied with taking care of their children rather than doing scientific research. Additionally, due to the lockdown, the researchers did not have enough time to carry out the administrative activities.

The COVID-19 pandemic has greatly affected the small-scale businesses as compared to the large-scale businesses [113]. Similarly, self-employed persons were more affected than the salaried persons [114]. It is observed that $43 \%$ of small-scale businesses were shut down by the end of December 2020 [115]. The female owners of small-scale businesses faced a $35 \%$ more loss than the male owners. The minorities in both developing and developed countries were greatly affected from COVID-19 [116]. After the COVID-19 duration, the digital economy will be extensively used by the entrepreneurs. The digital platforms will be used to advertise and sell the products [117]. The entrepreneurs can use online communities to find new collaborates, envisage new opportunities, and acquire the assistance to solve the particular problem [118]. Hence, there is no need to move the entrepreneurs from place to another for establishing their business.

Due to the strict lockdown, the elderly and disabled population are greatly affected from mental health problems. During the strict lockdown period, these persons suffer from depression, sleep disturbances, and anxiety. However, these problems cannot be eliminated by using the latest technology in the lockdown duration [119]. These population are unable to use the latest technology. Hence, there is a need to organize webinars or workshops on the use of digital technology for elderly and disabled population. COVID-19 put positive impacts on the environmental health due to the reduction in harmful gases from industrial activities. In addition to this, the negative impacts are also perceived on the environment. Human beings were restricted to their home for doing their business, and other activities, which led to an indoor pollution [47]. The proper ventilation and waste management are required to discontinue the spread of coronavirus infection. The improper treatment of unused medical wastes such as gloves, masks, and gowns may produce a new environmental problem. 


\section{Conclusions}

The COVID-19 pandemic has caused a dramatic loss to human life. It has drastically affected almost all the areas of human life. This study investigated the environmental health, social-economic impacts, and strategic plans to alleviate the influence of COVID-19 on different sectors. The disabled and old aged persons were unable to use the modern technologies for subscription services and latest information on pandemic. Governments should take an initiative for providing the basic amenities, accommodation, and digital technology to older and disable persons. Education sector is not an exception. Online learning mechanisms were used to compensate the theoretical concepts. However, the practical learning is drastically affected from this pandemic.

The number of foreign tourist arrivals decreased by $84 \%$ from March to December 2020 as compared to the previous year. After the relaxation in COVID-19 restrictions and vaccination, a modest improvement has been shown in the tourism industry especially in Mexico and the Caribbean. The chances are very high for the implementation of travel restrictions in more globalized countries. However, some states were not provided the actual data of COVID-19 outbreak due to the panic of economic crisis. Social globalization has resilient impact on the policy implementation. Despite the negative impacts on globalization and society, COVID-19 provided a better situation for improving the environmental health. The change in lifestyle of human beings greatly reduced the emission of carbon. The effective and efficient measures are required to handle the water waste and medical waste, such as masks, gloves, etc.

In future, the risk management of tourists travel after the COVID-19 pandemic will be investigated. The impact of lockdown on small businesses, young women, children, and rural areas can be analyzed to develop the effective plans for future pandemics.

Author Contributions: Conceptualization, V.K. and H.A.; Data curation, V.K. and H.A.; Formal analysis, V.K. and H.A.; Funding acquisition, S.A.I. and S.B.; Investigation, V.K., H.A., S.A.I. and S.B.; Validation, S.A.I. and S.B.; Writing-original draft, V.K. and H.A.; Writing—review and editing, V.K., H.A. and S.B. All authors have read and agreed to the published version of the manuscript.

Funding: The authors extend their appreciation to the Deanship of Scientific Research at King Khalid University for funding this work through the Research Groups Program under Grant RGP.2/53/42. They would also like to thank the Taif University Researchers Supporting Project (TURSP-2020/26), Taif University, Taif, Saudi Arabia.

Institutional Review Board Statement: Not applicable.

Informed Consent Statement: Not applicable.

Data Availability Statement: Not applicable.

Conflicts of Interest: The authors declare no conflict of interest.

\section{References}

1. Mark, H. Historical keyword Pandemic. Lancet 2009, 373, 1939.

2. Troncoso, A. Zika threatens to become a huge worldwide pandemic. Asian Pac. J. Trop. Biomed. 2016, 6, 520-527. [CrossRef]

3. Gostin, L.O.; Tomori, O.; Wibulpolprasert, S.; Jha, A.K.; Frenk, J.; Moon, S.; Phumaphi, J.; Piot, P.; Stocking, B.; Dzau, V.J.; et al. Toward a common secure future: Four global commissions in the wake of Ebola. PLoS Med. 2016, 13, e1002042. [CrossRef]

4. Rewar, S.; Mirdha, D.; Rewar, P. Treatment and prevention of pandemic H1N1 influenza. Ann. Glob. Health 2015, 81, 645-653. [CrossRef] [PubMed]

5. Maurice, J. Cost of protection against pandemics is small. Lancet 2016, 387, e12. [CrossRef]

6. Nabarro, D.; Wannous, C. The links between public and ecosystem health in light of the recent Ebola outbreaks and pandemic emergence. EcoHealth 2016, 13, 227-229. [CrossRef] [PubMed]

7. Kumar, P.; Morawska, L. Could fighting airborne transmission be the next line of defence against COVID-19 spread? City Environ. Interact. 2019, 4, 100033. [CrossRef] [PubMed]

8. Andersen, K.G.; Rambaut, A.; Lipkin, W.I.; Holmes, E.C.; Garry, R.F. The proximal origin of SARS-CoV-2. Nat. Med. 2020, 26, 450-452. [CrossRef] [PubMed]

9. Wan, Y.; Shang, J.; Graham, R.; Baric, R.S.; Li, F. Receptor recognition by the novel coronavirus from Wuhan: An analysis based on decade-long structural studies of SARS coronavirus. J. Virol. 2020, 94, e00127-20. [CrossRef] [PubMed] 
10. Cui, J.; Li, F.; Shi, Z.L. Origin and evolution of pathogenic coronaviruses. Nat. Rev. Microbiol. 2019, 17, 181-192. [CrossRef]

11. Bosch, B.J.; Van der Zee, R.; De Haan, C.A.; Rottier, P.J. The coronavirus spike protein is a class I virus fusion protein: Structural and functional characterization of the fusion core complex. J. Virol. 2003, 77, 8801-8811. [CrossRef] [PubMed]

12. Kwong, K.C.N.K.; Mehta, P.R.; Shukla, G.; Mehta, A.R. COVID-19, SARS and MERS: A neurological perspective. J. Clin. Neurosci. 2020, 77, 13-16. [CrossRef]

13. Worldometers. COVID-19 Coronavirus Pandemic. 2021. Available online: https://www.worldometers.info/coronavirus/ (accessed on 21 September 2021).

14. Jiang, P.; Fu, X.; Van Fan, Y.; Klemeš, J.J.; Chen, P.; Ma, S.; Zhang, W. Spatial-temporal potential exposure risk analytics and urban sustainability impacts related to COVID-19 mitigation: A perspective from car mobility behaviour. J. Clean. Prod. 2021, 279, 123673. [CrossRef]

15. Mofijur, M.; Fattah, I.R.; Alam, M.A.; Islam, A.S.; Ong, H.C.; Rahman, S.A.; Najafi, G.; Ahmed, S.F.; Uddin, M.A.; Mahlia, T.M.I. Impact of COVID-19 on the social, economic, environmental and energy domains: Lessons learnt from a global pandemic. Sustain. Prod. Consum. 2021, 26, 343-359. [CrossRef]

16. Singh, D.; Kumar, V.; Yadav, V.; Kaur, M. Deep Convolutional Neural Networks based Classification model for COVID-19 Infected Patients using Chest X-ray Images. Int. J. Pattern Recognit. Artif. Intell. 2021, 35, 2151004. [CrossRef]

17. Singh, J.; Singh, J. COVID-19 and its impact on society. Electron. Res. J. Soc. Sci. Humanit. 2020, 2, 168-172.

18. Davies, N.G.; Klepac, P.; Liu, Y.; Prem, K.; Jit, M.; Eggo, R.M. Age-dependent effects in the transmission and control of COVID-19 epidemics. Nat. Med. 2020, 26, 1205-1211. [CrossRef] [PubMed]

19. Chakraborty, I.; Maity, P. COVID-19 outbreak: Migration, effects on society, global environment and prevention. Sci. Total Environ. 2020, 728, 138882. [CrossRef] [PubMed]

20. Lebrasseur, A.; Fortin-Bédard, N.; Lettre, J.; Raymond, E.; Bussières, E.L.; Lapierre, N.; Faieta, J.; Vincent, C.; Duchesne, L.; Ouellet, M.C.; et al. Impact of the COVID-19 Pandemic on Older Adults: Rapid Review. JMIR Aging 2021, 4, e26474. [CrossRef]

21. Wong, S.Y.S.; Zhang, D.; Sit, R.W.S.; Yip, B.H.K.; Chung, R.Y.N.; Wong, C.K.M.; Chan, D.C.C.; Sun, W.; Kwok, K.O.; Mercer, S.W. Impact of COVID-19 on loneliness, mental health, and health service utilisation: A prospective cohort study of older adults with multimorbidity in primary care. Br. J. Gen. Pract. 2020, 70, e817-e824. [CrossRef]

22. Heid, A.R.; Cartwright, F.; Wilson-Genderson, M.; Pruchno, R. Challenges experienced by older people during the initial months of the COVID-19 pandemic. Gerontologist 2021, 61, 48-58. [CrossRef] [PubMed]

23. Xie, B.; Charness, N.; Fingerman, K.; Kaye, J.; Kim, M.T.; Khurshid, A. When going digital becomes a necessity: Ensuring older adults' needs for information, services, and social inclusion during COVID-19. J. Aging Soc. Policy 2020, 32, 460-470. [CrossRef]

24. UN IANYD Statement on COVID-19 and Youth. 2020. Available online: https://www.un.org/development/desa/youth/news/ 2020/04/unianyd/ (accessed on 30 September 2021).

25. The Impact of COVID-19 on Young People. 2020. Available online: https://www.generationunlimited.org/stories/impact-covid19-young-people (accessed on 26 September 2021).

26. Youth and COVID-19: Impact on Jobs, Education, Rights, and Mental Well-Being. 2020. Available online: https://www.ilo.org/ wcmsp5/groups/public/---ed_emp/documents/publication/wcms_753026.pdf (accessed on 30 September 2021).

27. The Impact of COVID-19 on Young People \& the Youth Sector. 2020. Available online: https://www.ukyouth.org/wp-content/ uploads/2021/01/UK-Youth-Covid-19-Impact-Report-.pdf (accessed on 30 September 2021).

28. Moore, S.A.; Faulkner, G.; Rhodes, R.E.; Brussoni, M.; Chulak-Bozzer, T.; Ferguson, L.J.; Mitra, R.; O’Reilly, N.; Spence, J.C.; Vanderloo, L.M.; et al. Impact of the COVID-19 virus outbreak on movement and play behaviours of Canadian children and youth: A national survey. Int. J. Behav. Nutr. Phys. Act. 2020, 17, 1-11. [CrossRef]

29. Young Workers in the Coronavirus Crisis: Findings from the Resolution Foundation's Coronavirus Survey. 2020. Available online: https://www.resolutionfoundation.org/publications/young-workers-in-the-coronavirus-crisis / (accessed on 25 September 2021).

30. Disability Considerations during the COVID-19 Outbreak. 2020. Available online: https://www.who.int/publications/i/item/ WHO-2019-nCoV-Disability-2020-1 (accessed on 28 September 2021).

31. Jeon, G. COVID-19 and the lives of disabled persons: The current status and countermeasures. J. Crit. Soc. Welf. 2020, 68, 173-207. [CrossRef]

32. Due to Prolonged COVID-19, Disabled People Suffer Physically and Mentally. 2021. Available online: http://www.ablenews.co. $\mathrm{kr} /$ News/NewsPrint/ (accessed on 23 September 2021).

33. Banks, L.M.; Davey, C.; Shakespeare, T.; Kuper, H. Disability-inclusive responses to COVID-19: Lessons learnt from research on social protection in low-and middle-income countries. World Dev. 2021, 137, 105178. [CrossRef] [PubMed]

34. Roser, M.; Ritchie, H.; Ortiz-Ospina, E. World Population Growth. Our World in Data 2019. Available online: https: // ourworldindata.org/world-population-growth (accessed on 10 October 2021).

35. Hoban, S.; Campbell, C.D.; da Silva, J.M.; Ekblom, R.; Funk, W.C.; Garner, B.A.; Godoy, J.A.; Kershaw, F.; MacDonald, A.J.; Mergeay, J.; et al. Genetic diversity is considered important but interpreted narrowly in country reports to the Convention on Biological Diversity: Current actions and indicators are insufficient. Biol. Conserv. 2021, 261, 109233. [CrossRef]

36. Alves de Oliveira, B.F.; Bottino, M.J.; Nobre, P.; Nobre, C.A. Deforestation and climate change are projected to increase heat stress risk in the Brazilian Amazon. Commun. Earth Environ. 2021, 2, 207. [CrossRef] 
37. Preventing the Next Pandemic: Zoonotic Diseases and How to Break the Chain of Transmission. 2020. Available online: https:// www.unep.org/resources/report/preventing-future-zoonotic-disease-outbreaks-protecting-environment-animals-and (accessed on 12 October 2021).

38. Rohr, J.R.; Barrett, C.B.; Civitello, D.J.; Craft, M.E.; Delius, B.; DeLeo, G.A.; Hudson, P.J.; Jouanard, N.; Nguyen, K.H.; Ostfeld, R.S.; et al. Emerging human infectious diseases and the links to global food production. Nat. Sustain. 2019, 2, 445-456. [CrossRef]

39. Global Assessment Report on Biodiversity and Ecosystem Services. 2017. Available online: https://ipbes.net/global-assessment (accessed on 12 October 2021).

40. Li, L.; Li, Q.; Huang, L.; Wang, Q.; Zhu, A.; Xu, J.; Liu, Z.; Li, H.; Shi, L.; Li, R.; et al. Air quality changes during the COVID-19 lockdown over the Yangtze River Delta Region: An insight into the impact of human activity pattern changes on air pollution variation. Sci. Total Environ. 2020, 732, 139282. [CrossRef]

41. SARS Death Rate Doubles in Polluted Cities. 2003. Available online: https://www.sciencedaily.com/releases/2003/11/03112007 3707.htm (accessed on 25 September 2021).

42. State of Global Air: A Special Report on Global Exposure to Air Pollution and Its Disease Burden. 2018. Available online: https:/ / www.stateofglobalair.org/sites/default/files/soga-2018-report.pdf (accessed on 27 September 2021).

43. Wu, X.; Nethery, R.C.; Sabath, B.M.; Braun, D.; Dominici, F. Exposure to air pollution and COVID-19 mortality in the United States. medRxiv 2020. [CrossRef]

44. Chen, L.W.A.; Chien, L.C.; Li, Y.; Lin, G. Nonuniform impacts of COVID-19 lockdown on air quality over the United States. Sci. Total Environ. 2020, 745, 141105. [CrossRef]

45. Mahato, S.; Pal, S.; Ghosh, K.G. Effect of lockdown amid COVID-19 pandemic on air quality of the megacity Delhi, India. Sci. Total Environ. 2020, 730, 139086. [CrossRef] [PubMed]

46. Streiff, L. NASA Model Reveals How Much COVID-Related Pollution Levels Deviated from the Norm. 2020. Available online: https:/ / www.nasa.gov/feature/goddard/2020/nasa-model-reveals-how-much-covid-related-pollution-levels-deviatedfrom-the-norm (accessed on 24 September 2021).

47. Agarwal, A.; Sharma, S.; Kumar, V.; Kaur, M. Effect of E-learning on public health and environment during COVID-19 lockdown. Big Data Min. Anal. 2021, 4, 104-115. [CrossRef]

48. Girdhar, A.; Kapur, H.; Kumar, V.; Kaur, M.; Singh, D.; Damasevicius, R. Effect of COVID-19 outbreak on urban health and environment. Air Qual. Atmos. Health 2021, 14, 389-397. [CrossRef] [PubMed]

49. Dutta, V.; Dubey, D.; Kumar, S. Cleaning the River Ganga: Impact of lockdown on water quality and future implications on river rejuvenation strategies. Sci. Total Environ. 2020, 743, 140756. [CrossRef]

50. Lockdown Effect: Ganga Water Fit for Drinking after Decades. 2020. Available online: https:/ /www.newindianexpress.com/ nation/2020/may/08/lockdown-effect-ganga-water-fit-for-drinking-after-decades-say-experts-2140622.html (accessed on 13 October 2021).

51. Saadat, S.; Rawtani, D.; Hussain, C.M. Environmental perspective of COVID-19. Sci. Total Environ. 2020, 728, 138870. [CrossRef]

52. Mariani, G.; Cheung, W.W.; Lyet, A.; Sala, E.; Mayorga, J.; Velez, L.; Gaines, S.D.; Dejean, T.; Troussellier, M.; Mouillot, D. Let more big fish sink: Fisheries prevent blue carbon sequestration-Half in unprofitable areas. Sci. Adv. 2020, 6, eabb4848. [CrossRef]

53. Manzo, G.G. The Economic Impact of Global Wildlife Tourism. 2020. Available online: https://travesiasdigital.com/wp-content/ uploads/2019/08/The-Economic-Impact-of-Global-Wildlife-Tourism-Final-19.pdf (accessed on 28 September 2021).

54. Loh, H.C.; Looi, I.; Ch'ng, A.S.H.; Goh, K.W.; Ming, L.C.; Ang, K.H. Positive global environmental impacts of the COVID-19 pandemic lockdown: A review. GeoJournal 2021. [CrossRef]

55. Rutz, C.; Loretto, M.C.; Bates, A.E.; Davidson, S.C.; Duarte, C.M.; Jetz, W.; Johnson, M.; Kato, A.; Kays, R.; Mueller, T.; et al. COVID-19 lockdown allows researchers to quantify the effects of human activity on wildlife. Nat. Ecol. Evol. 2020, 4, 1156-1159. [CrossRef] [PubMed]

56. Debata, B.; Patnaik, P.; Mishra, A. COVID-19 pandemic: It's impact on people, economy, and environment. J. Public Aff. 2020, 20, e2372. [CrossRef]

57. Erken, H.; Middeldorp, M.; Hayat, R.; Ji, K. Global Economic Outlook: COVID-19 Has Taken a Hold of the Global Economy. 2020. Available online: https:/ / economics.rabobank.com/publications/2020/march/global-economic-outlook (accessed on 15 October 2021).

58. Gopinath, G. The great lockdown: Worst economic downturn since the great depression. IMF Blog, 14 April 2020. Available online: https:/ /blogs.imf.org/2020/04/14/the-great-lockdown-worst-economic-downturn-since-the-great-depression (accessed on 17 October 2021).

59. Sogani, A. The Great Lockdown vs. The Great Depression and the 2008 Global Financial Crisis. E-International Relations, 2 July 2020. Available online: https://www.e-ir.info/pdf/ 85743 (accessed on 14 October 2021).

60. McKibbin, W.; Fernando, R. The Economic Impact of COVID-19; Centre for Economic Policy Research: London, UK, 2020; Volume 45.

61. Siche, R. What is the impact of COVID-19 disease on agriculture? Scientia Agropecuaria 2020, 11, 3-6. [CrossRef]

62. Štreimikienè, D.; Baležentis, T.; Volkov, A.; Ribašauskienè, E.; Morkūnas, M.; Žičkienè, A. Negative effects of covid-19 pandemic on agriculture: Systematic literature review in the frameworks of vulnerability, resilience and risks involved. Econ. Res.-Ekonomska Istraživanja 2021. [CrossRef] 
63. Niles, M.T.; Bertmann, F.; Belarmino, E.H.; Wentworth, T.; Biehl, E.; Neff, R. The early food insecurity impacts of COVID-19. Nutrients 2020, 12, 2096. [CrossRef] [PubMed]

64. COVID-19 Will Double Number of People Facing Food Crises Unless Swift Action Is Taken. 2020. Available online: https:/ www.wfp. $\mathrm{org} /$ news / covid-19-will-double-number-people-facing-food-crises-unless-swift-action-taken (accessed on 25 September 2021).

65. Clapp, J.; Moseley, W.G. This food crisis is different: COVID-19 and the fragility of the neoliberal food security order. J. Peasant. Stud. 2020, 47, 1393-1417. [CrossRef]

66. Cariappa, A.A.; Acharya, K.K.; Adhav, C.A.; Sendhil, R.; Ramasundaram, P. Impact of COVID-19 on the Indian agricultural system: A 10-point strategy for post-pandemic recovery. Outlook Agric. 2021, 50, 26-33. [CrossRef]

67. Pedauga, L.; Sáez, F.; Delgado-Márquez, B.L. Macroeconomic lockdown and SMEs: The impact of the COVID-19 pandemic in Spain. Small Bus. Econ. 2021. [CrossRef]

68. Shafi, M.; Liu, J.; Ren, W. Impact of COVID-19 pandemic on micro, small, and medium-sized Enterprises operating in Pakistan. Res. Glob. 2020, 2, 100018. [CrossRef]

69. Tripathy, S.; Bisoyi, T. Detrimental impact of COVID-19 pandemic on micro, small and medium enterprises in India. Jharkhand J. Dev. Manag. Stud. 2021, 19, 8651-8660.

70. Syal, S. Role of MSMEs in the growth of Indian economy. Glob. J. Commer. Manag. Perspect. 2015, 4, 40-43.

71. A Quarter of MSMEs May Shut Shop If the Lockdown Persists. 2020. Available online: https://economictimes.indiatimes.com/ small-biz/sme-sector/a-quarter-of-msmes-may-shut-shop-if-the-lockdown-persists / articleshow /74880940.cms? from=mdr (accessed on 12 October 2021).

72. Moon, S. Effects of COVID-19 on the Entertainment Industry. IDOSR J. Exp. Sci. 2020, 5, 8-12.

73. Nhamo, G.; Dube, K.; Chikodzi, D. Implications of COVID-19 on gaming, leisure and entertainment industry. In Counting the Cost of COVID-19 on the Global Tourism Industry; Springer: Berlin/Heidelberg, Germany, 2020; pp. 273-295.

74. Etemad-Sajadi, R. The impact of online real-time interactivity on patronage intention: The use of avatars. Comput. Hum. Behav. 2016, 61, 227-232. [CrossRef]

75. Abbas, J.; Mubeen, R.; Iorember, P.T.; Raza, S.; Mamirkulova, G. Exploring the impact of COVID-19 on tourism: Transformational potential and implications for a sustainable recovery of the travel and leisure industry. Curr. Res. Behav. Sci. 2021, 2, 100033. [CrossRef]

76. Aguiar, A.; Chepeliev, M.; Corong, E.; McDougall, R.; Van der Mensbrugghe, D. The GTAP Data Base: Version 10. J. Glob. Econ. Anal. 2019, 4, 1-27. [CrossRef]

77. Gricar, S.; Baldigara, T.; Šugar, V. Sustainable Determinants That Affect Tourist Arrival Forecasting. Sustainability 2021, 13, 9659. [CrossRef]

78. Rahman, M.K.; Gazi, M.A.I.; Bhuiyan, M.A.; Rahaman, M.A. Effect of Covid-19 pandemic on tourist travel risk and management perceptions. PLoS ONE 2021, 16, e0256486. [CrossRef]

79. Tourism and COVID-19-Unprecedented Economic Impacts. 2021. Available online: https://www.unwto.org/tourism-andcovid-19-unprecedented-economic-impacts (accessed on 16 October 2021).

80. Foo, L.P.; Chin, M.Y.; Tan, K.L.; Phuah, K.T. The impact of COVID-19 on tourism industry in Malaysia. Curr. Issues Tour. 2020, 24, 2735-2739. [CrossRef]

81. Dash, J. COVID-19 Impact: Tourism Industry to Incur Rs 1.25 Trn Revenue Loss in 2020. 2020. Available online: https: / / www.business-standard.com/article/economy-policy/covid-19-impact-tourism-industry-to-incur-rs-1-25-trnrevenue-loss-in-2020-120042801287_1.html (accessed on 16 October 2021).

82. Gautam, P. The Effects and Challenges of COVID-19 in the Hospitality and Tourism Sector in India. J. Tour. Hosp. Educ. 2021, 11, 43-63. [CrossRef]

83. Impact of COVID-19 on Tourism in Small Island Developing States. 2020. Available online: https://unctad.org/news/impactcovid-19-tourism-small-island-developing-states (accessed on 14 October 2021).

84. Sahoo, P.; Ashwani. COVID-19 and Indian economy: Impact on growth, manufacturing, trade and MSME sector. Glob. Bus. Rev. 2020, 21, 1159-1183. [CrossRef]

85. Coronavirus Could Shrink Global FDI by 5\% to 15\%. 2020. Available online: https://unctad.org/news/coronavirus-couldshrink-global-fdi-5-15 (accessed on 28 September 2021).

86. Prasad, R.S. Almost 25 Million Jobs Could Be Lost Worldwide as a Result of COVID-19, Says International Labour Organization (ILO). 2020. Available online: https://www.ilo.org/global/about-the-ilo/newsroom/news/WCMS_738742/lang--en/index.htm (accessed on 25 September 2021).

87. Engzell, P.; Frey, A.; Verhagen, M.D. Learning loss due to school closures during the COVID-19 pandemic. Proc. Natl. Acad. Sci. USA 2021, 118, e2022376118. [CrossRef]

88. Viner, R.M.; Russell, S.J.; Croker, H.; Packer, J.; Ward, J.; Stansfield, C.; Mytton, O.; Bonell, C.; Booy, R. School closure and management practices during coronavirus outbreaks including COVID-19: A rapid systematic review. Lancet Child Adolesc. Health 2020, 4, 397-404. [CrossRef]

89. Schleicher, A. The Impact of COVID-19 on Education Insights from Education at a Glance. 2020. Available online: https: / / www.oecd.org/education/the-impact-of-covid-19-on-education-insights-education-at-a-glance-2020.pdf (accessed on 30 August 2021). 
90. Magomedov, I.; Khaliev, M.S.; Khubolov, S. The negative and positive impact of the pandemic on education. J. Phys. Conf. Ser. 2020, 1691, 012134. [CrossRef]

91. COVID-19 Educational Disruption and Response. 2020. Available online: https://en.unesco.org/news/covid-19-educationaldisruption-and-response (accessed on 15 October 2021).

92. Jena, P. Impact of pandemic covid-19 on education in india. Int. J. Curr. Res. 2020, 12, 12582-12586.

93. PriyankaPanditaKoul, P.; Bapat, O. Impact of covid-19 on education sector in india. J. Crit. Rev. 2020, 7, 3919-3930.

94. Miki, Y.; Chubachi, N.; Imamura, F.; Yaegashi, N.; Ito, K. Impact of COVID-19 restrictions on the research environment and motivation of researchers in Japan. Prog. Disaster Sci. 2020, 8, 100128. [CrossRef]

95. Estimates of Funding for Various Research, Condition, and Disease Categories (RCDC). 2020. Available online: https://report. nih.gov/categorical_spending.aspx (accessed on 15 October 2021).

96. Kumar, V.; Singh, D.; Kaur, M.; Damaševičius, R. Overview of current state of research on the application of artificial intelligence techniques for COVID-19. PeerJ Comput. Sci. 2021, 7, e564. [CrossRef] [PubMed]

97. Alshazly, H.; Linse, C.; Barth, E.; Martinetz, T. Explainable COVID-19 detection using chest CT scans and deep learning. Sensors 2021, 21, 455. [CrossRef] [PubMed]

98. Singh, D.; Kumar, V.; Kaur, M.; Jabarulla, M.Y.; Lee, H.N. Screening of COVID-19 Suspected Subjects Using Multi-Crossover Genetic Algorithm Based Dense Convolutional Neural Network. IEEE Access 2021, 9, 142566-142580. [CrossRef]

99. Alshazly, H.; Linse, C.; Abdalla, M.; Barth, E.; Martinetz, T. COVID-Nets: Deep CNN architectures for detecting COVID-19 using chest CT scans. Peer] Comput. Sci. 2021, 7, e655. [CrossRef] [PubMed]

100. Gianchandani, N.; Jaiswal, A.; Singh, D.; Kumar, V.; Kaur, M. Rapid COVID-19 diagnosis using ensemble deep transfer learning models from chest radiographic images. J. Ambient. Intell. Humaniz. Comput. 2020. [CrossRef]

101. The Pandemic Claims New Victims: Prestigious Medical Journals. 2020. Available online: https://www.nytimes.com/2020/06/ 14/health/virus-journals.html (accessed on 15 November 2021).

102. Mehra, M.R.; Ruschitzka, F.; Patel, A.N. Retraction-Hydroxychloroquine or chloroquine with or without a macrolide for treatment of COVID-19: A multinational registry analysis. Lancet 2020, 395, 1820. [CrossRef]

103. Valencise, F.E.; Boschiero, M.N.; Palamim, C.; Marson, F. The COVID-19 impact on the scientific production on the 25 main death causes according to world region. Pulmonology 2021. [CrossRef]

104. Harper, L.; Kalfa, N.; Beckers, G.; Kaefer, M.; Nieuwhof-Leppink, A.J.; Fossum, M.; Herbst, K.W.; Bagli, D.; Committee, E.R. The impact of COVID-19 on research. J. Pediatr. Urol. 2020, 16, 715-716. [CrossRef] [PubMed]

105. Bickley, S.J.; Chan, H.F.; Skali, A.; Stadelmann, D.; Torgler, B. How does globalization affect COVID-19 responses? Glob. Health 2021, 17, 1-19. [CrossRef] [PubMed]

106. Martens, P.; Akin, S.M.; Maud, H.; Mohsin, R. Is globalization healthy: A statistical indicator analysis of the impacts of globalization on health. Glob. Health 2010, 6, 1-14. [CrossRef]

107. Farzanegan, M.R.; Feizi, M.; Gholipour, H.F. Globalization and the outbreak of COVID-19: An empirical analysis. J. Risk Financ. Manag. 2021, 14, 105. [CrossRef]

108. COVID-19 and the World of Work: Impact and Policy Responses. 2020. Available online: https://www.ilo.org/wcmsp5/groups/ public/---dgreports/---dcomm/documents/briefingnote/ (accessed on 14 October 2021).

109. Shrestha, N.; Shad, M.Y.; Ulvi, O.; Khan, M.H.; Karamehic-Muratovic, A.; Nguyen, U.S.D.; Baghbanzadeh, M.; Wardrup, R.; Aghamohammadi, N.; Cervantes, D.; et al. The impact of COVID-19 on globalization. One Health 2020, 11, 100180. [CrossRef]

110. Capano, G.; Howlett, M.; Jarvis, D.S.; Ramesh, M.; Goyal, N. Mobilizing policy (in) capacity to fight COVID-19: Understanding variations in state responses. Policy Soc. 2020, 39, 285-308. [CrossRef]

111. Barlow, P.; Labonte, R.; McKee, M.; Stuckler, D. Trade challenges at the World Trade Organization to national noncommunicable disease prevention policies: A thematic document analysis of trade and health policy space. PLoS Med. 2018, 15, e1002590. [CrossRef]

112. The COVID-19 Pandemic Has Changed Education Forever. This Is How. 2021. Available online: https://www.weforum.org/ agenda/2020/04/coronavirus-education-global-covid19-online-digital-learning/ (accessed on 16 October 2021).

113. Bartik, A.W.; Bertrand, M.; Cullen, Z.; Glaeser, E.L.; Luca, M.; Stanton, C. The impact of COVID-19 on small business outcomes and expectations. Proc. Natl. Acad. Sci. USA 2020, 117, 17656-17666. [CrossRef]

114. Dörr, J.; Licht, G.; Murmann, S. Small firms and the COVID-19 insolvency gap. Small Bus. Econ. 2021. [CrossRef]

115. Clauss, T.; Abebe, M.; Tangpong, C.; Hock, M. Strategic Agility, Business Model Innovation, and Firm Performance: An Empirical Investigation. IEEE Trans. Eng. Manag. 2019, 68, 767-784. [CrossRef]

116. Fairlie, R.; Fossen, F.M. Did the Paycheck Protection Program and Economic Injury Disaster Loan Program get disbursed to minority communities in the early stages of COVID-19? Small Bus. Econ. 2021. [CrossRef]

117. European Small Businesses Find a Digital Safety Net during COVID-19. Report. 2021. Available online: https://digitallydriven. connectedcouncil.org/europe/ (accessed on 15 October 2021).

118. Meurer, M.M.; Waldkirch, M.; Schou, P.K.; Bucher, E.L.; Burmeister-Lamp, K. Digital affordances: How entrepreneurs access support in online communities during the COVID-19 pandemic. Small Bus. Econ. 2021. [CrossRef]

119. Minhae, C.; Kim, K.M. Effect of digital divide on people with disabilities during the Covid-19 pandemic. Disabil. Health J. 2021, 101214 , in press. 